Hilmi Kacar,

\title{
A Mirror for the Sultan: State Ideology in the Early Ottoman Chronicles,
} 1300-1453,

Universiteit Gent, Faculteit Letteren \& Wijsbegeerte, 2015, 376 pp., no ISBN.

The last decade or so has witnessed a rise in the scholarly output on the early Ottomans, especially within the context of the development of Ottoman historiography, with particular reference to how the Ottomans viewed themselves. Discourse on the early Ottoman state sought to no longer view the Ottomans through the lens of earlier theories on the rise of the Ottoman state such as Paul Wittek's "Ghazi thesis" and instead pursued the redefining of labels of a religious and cultural nature that had previously been ascribed to the Ottomans by modern scholarship. ${ }^{2}$ It is within this context that the work under scrutiny should be considered. It is Kacar's approach to studying of early Ottoman history that renders his book unique rather than the topic itself, which has been the subject of much scholarly debate of late. Kacar's aim is to explore the possibility of going beyond the 'orientalist' and 'colonial' premises and descriptions of Ottoman history and to let the Ottomans speak for themselves in their own words (p. 7). In common with recent scholarly output Kacar argues that the sources of the early Ottoman state should not be utilised to bring light to modern theories on the rise of the Ottomans. As an example of this, Kacar refutes the "Ghazi thesis" of Paul Wittek that the raison d'être of the early Ottomans was holy war and uses the discourse of the chroniclers to demonstrate that the notion of ghaza had various dimensions and carried various ideological connotations (p. 352).

The author's implementation of Norman Fairclough's methodologies of 'Critical Discourse Analysis' (CDA) is a breath of fresh air to the field of Ottoman

1 Paul Wittek, The Rise of the Ottoman Empire, (London: Royal Asiatic Society Monographs, 1963 ed.)

2 Cemal Kadafar, Between Two Worlds: The Construction of the Ottoman State (Los Angeles: University of California Press, 1995), Murat Cem Mengüç, "Histories of Bayezid I, historians of Bayezid II: Rethinking late fifteenth-century Ottoman historiography," Bulletin of the School of Oriental and African Studies (Volume 76 / Issue 03 / October 2013, pp 373-389) and Lale Özdemir, Ottoman History Through The Eyes of Aşıkpaşazade (İstanbul: Isis Press 2013) can be considered as examples of scholarship that allows for fluidity and heterogeneity where the early Ottomans are concerned. 
studies. Kacar attempts "to make early Ottoman history somewhat more intelligible by trying to understand the 'political language' or 'state ideology' as the earliest Ottoman chronicles formulated it in their own words" (p. 355). Thus, his primary focus is on Ottoman state ideology and he argues that the advantage of using Critical Discourse Analysis is that it takes the narrative of the texts seriously and considers them valuable (p. 4) The fact that this method departs from the idea that value judgments are pervasively present in discourse is a blessing given that an abundance of value judgments have been attached to fifteenth-century Ottoman sources in order to bring light to modern theories on the rise of the Ottomans. Most commonly, such value judgments have centered on whether the early Ottomans were indeed ghazis or not. ${ }^{3}$ Kacar's observation within the context of Critical Discourse Analysis that an exaggerated form of historical criticism can unwillingly become a sort of orientalist view, which in turn does not allow the 'Orientals' (in this case the Ottomans) to speak for themselves is a valid and necessary one (p. 3).

The first of the three chapters of $A$ Mirror for the Sultan sets the scene of early Ottoman historiography and includes a comprehensive discussion of the sources of the period. Kacar adopts the term 'early Ottoman historical texts' and categorises the discussion of historical texts, essentially chronicles, chronologically as follows; early fifteenth-century chronicles, the period of Murad II (r. 1421-1451), chronicles from the period of Mehmed II (1451-1481), and chronicles from the period of Bâyezid II (1481-1512). In this chapter the author argues that while the Ottoman chronicle tradition obviously should be treated with great caution and that a positivist application of source criticism adopted by some modern scholars is not helpful as such an approach does not allow the Ottomans to speak for themselves (p. 24).

In the second chapter, Kacar examines patterns of state formation in the early Ottoman empire, c. 1300-1453, and asserts that a comprehensive overview of the state formation processes at work is necessary in order to be able to comprehend the origins of state ideology (p. 59). Kacar provides a chronological-based discussion of the pre-Ottoman states not only from a political but also a cultural

3 Scholars have usually been assigned a place in the pro-Wittekian or anti-Wittekian camp with regard to the "Ghazi thesis." However, over the last decade or so a new generation of scholars have chosen not to get drawn into the debate over whether the early Ottoman state expanded its territories in name of holy war. For example, Karen Barkey, Empire of Difference: The Ottomans in Comparative Perspective (Cambridge: Cambridge University Press, 2008). 
perspective by stressing the role of dialogue and mutually beneficial relationship between Muslim and non-Muslim populations (p. 78). Kacar's narrative on the Ottomans' forbearers mirrors that of the late historian Mehmed Fuat Köprülü in that he adopts a somewhat traditional but still valuable view of how the pressure of Mongol expansion forced pastoral nomad communities to migrate to Anatolia (pp. 83-85). Kacar goes on to outline, in accordance with Ottoman tradition, how Osman Gazi (r. 1302-1326) became a bey after he had been selected as the leader of the Kayı-line of the Oğuz when his father Ertuğrul died in 1299.

It is in the third chapter that discusses the discursive registers of fifteenth century Ottoman state ideology, Kacar makes an important contribution to the field of Ottoman studies. According to him, early Ottoman chronicles reveal that they mostly rely on two traditions: nomadic Turkish political ideas and Islamic political thought (p. 185). Based on an examination of these sources, he sheds light on how different political cultures fused in order to meet the need for legitimacy that developed over time through changing historical landscapes. He skillfully evaluates the semantic meaning of concepts that represented paradigmatic ideas and constituted value systems which formed the powerful legitimising pillars of Ottoman political discourse (p. 185). Moreover, he analyses how the elements and notions originating from steppe nomadic and Islamic traditions were fused which meant that "the chroniclers selectively appropriated discursive registers from the available traditions and blended them into a political language of their own" (p. 198). Within this framework, Kacar scrutinizes several concepts such as Kut or divine dispensation, the principles of succession, and the influence of Islamic political thought on the institution of the monarchy within the context of the above two political traditions.

Overall, the author adopts a very engaging style which renders $A$ Mirror for the Sultan an easy read and although not all of the content can be considered as original contribution to Ottoman historiography, Kacar certainly advances the field with his analysis of state ideology within the context of 'Critical Discourse Analysis.'

\section{Lâle Özdemir}

